\title{
Wastewater use in irrigated agriculture
}

\author{
Pay Drechsel • Alexandra E. V. Evans
}

Published online: 9 April 2010

(C) Springer Science+Business Media B.V. 2010

Wastewater irrigation is a widespread phenomenon. Although its main drivers differ between regions and along the sanitation ladder, they clearly indicate that the practice will continue to increase. This is especially the case in low-income countries where farmers in the economically interesting peri-urban interface are hardly able to find unpolluted surface water sources, as a result of inadequate wastewater collection and treatment. In other countries, reuse of (usually treated) wastewater is an important strategy to cope with fresh water scarcity. Both water scarcity and the gap between population growth and investments in sanitation will without question continue to challenge us in years to come.

At present, more than $80 \%$ of the sewage generated in developing countries is discharged untreated into the environment, and about $50 \%$ of the population depends on polluted water sources for various uses, including irrigation (UNESCO 2003).

Global estimates of the total irrigated area under raw and diluted wastewater are still fragmentary, but are likely to range between 5 and 20 million hectares, with the largest share probably in China due to its severe water pollution problems. Poor wastewater treatment and resulting large scale water pollution also suggest that the share of area irrigated with unsafe wastewater is probably ten times larger than the area using treated wastewater (Scott et al. 2010). However, estimates are still rudimentary and much more work is required to fully understand the extent of this problem and its implications. The same applies to the affected population. Nearly two decades ago, Paul Lunven estimated that at least $10 \%$ of the world's population consumes food irrigated with wastewater (WHO 2006). Current estimates point at roughly one billion consumers of agricultural products initially grown with wastewater. A part of this group consumes raw produce, such as salad greens. In developing countries, these consumers face the most severe health risks, as only a small percentage of the wastewater undergoes sufficient treatment. 
In 2002, about 2.4 million people died from water and sanitation-associated diseases, nearly all in developing countries. Diarrhoea alone is responsible for $39 \%$ of the related disease burden and about $4 \%$ of the general global disease burden. The important message here, however, is that diarrhoea is a disease that can be largely attributed to environmental factors, such as unsafe drinking-water, poor hygiene and sanitation, or pathogencontaminated crops, all of which could be avoided (Prüss-Ustün et al. 2008). The exact share of the problem that can be attributed to food produced with wastewater irrigation is not yet known, and may comprise a relatively small share of the total, compared with poor access to safe drinking water, inadequate sanitation, and poor hygiene standards. However, wastewater irrigated food is likely a key pathway for epidemics. In Accra, Ghana, for example, every day about 200,000 urban dwellers eat fast food with raw salad leaves produced with highly polluted irrigation water (Amoah et al. 2007). But not everyone gets sick. Much more still needs to be known.

The global 'hotspots' for health risks related to wastewater irrigation, as well as possible epidemics, are specifically those countries and regions in which governments lack the capacity to invest in and operate wastewater treatment plants. The WHO is well aware of this challenge and in the 2006 version of its wastewater use guidelines, targets situations in which conventional wastewater collection and treatment are insufficient to protect public health. It should be noted that wastewater treatment is only one part of a suite of interventions suggested, though it usually forms part of the longer-term intervention strategy. Because the WHO guidelines are generic due to their global coverage, local adaptations are needed in both health risk assessments and local health mitigation measures. Applied research plays a significant role in this context as recently reinforced in the Accra Consensus (IWMI 2008).

This special issue of Irrigation and Drainage Systems is dedicated to this topic and complements a closely related new textbook on Wastewater Irrigation and Health (Drechsel et al. 2010). The articles in the issue provide overviews, address key challenges, provide new data, and, most importantly, give food for thought.

The articles address the contrasting expectations that stakeholder have in view of the 2006 edition of the WHO guidelines (Keraita et al.) and highlight the challenges associated with global assessment of wastewater irrigation (Raschid-Sally), while documenting the current state of knowledge on wastewater irrigation in the MENA region (Qadir et al.). The evidence presented in this issue suggests that the use of wastewater in agriculture and aquaculture can have more benefits than risks even when untreated, and after long term application (Simmons et al., Barker Reid et al., Holm et al.). It also suggests that appropriately designed irrigation infrastructure can reduce health risks by providing wastewater treatment (Ensink et al.). Both conclusions are good news.

It is important to analyse wastewater generation and use in the context of integrated urban water management (Van Rooijen et al.). In particular, nutrient recycling (Erni et al.) should be considered in urban planning to help conceptualize wastewater as an asset and to provide support and justification for investment in appropriate (nutrient conserving) wastewater treatment (van Lier and Huibers).

We hope the articles will inspire further interest and research in the topic to support WHO and FAO in their efforts to break wastewater-related pathogen cycles and enhance food safety. We would like to thank the researchers who responded to this call and provided research results or reviews for this special issue. Thanks also to the organizations and others who provided the funding to the various studies and the journal's Editor-in-Chief for his interest in highlighting this important topic. 


\section{References}

Amoah P, Drechsel P, Abaidoo RC, Henseler M (2007) Irrigated urban vegetable production in Ghana: microbiological contamination in farms and markets and associated consumer risk groups. J Water Health 5(3):455-466

Drechsel P, Scott CA, Raschid-Sally L, Redwood M, Bahri A (eds.) (2010) Wastewater irrigation and health: assessing and mitigation risks in low-income countries. Earthscan-IDRC-IWMI, UK; www.idrc.ca/en/ ev-149129-201-1-DO_TOPIC.html

IWMI (2008) www.iwmi.cyiar.org/Research_Impacts/Research_Themes/Theme_3/Accra_Consensus.aspx

Prüss-Üstün A, Bos R, Gore F, Bartram J (2008) Safer water, better health: costs, benefits and sustainability of interventions to protect and promote health. World Health Organization, Geneva

Scott C, Drechsel P, Raschid-Sally L, Bahri A, Mara D, Redwood M, Jiménez B (2010) Wastewater irrigation and health: challenges and outlook for mitigating risks in low-income countries. In: Drechsel P, Scott CA, Raschid-Sally L, Redwood M, Bahri A (eds.) Wastewater irrigation and health: Assessing and mitigation risks in low-income countries. Earthscan-IDRC-IWMI, UK; www.idrc.ca/en/ev-149129-2011-DO TOPIC.html

UNESCO (2003) Water for People, Water for Life. United Nations/World Water Assessment Programme, UNESCO, Paris and Berghahn Books, New York

World Health Organization (WHO) (2006) 'Guidelines for the Safe Use of Wastewater, Excreta and Greywater'. World Health Organization, Geneva 